\title{
Economic and legal aspects of transportation of cargo in Ukraine in the conditions of Euro integration
}

\author{
Nadiia Bocharova ${ }^{11}$, Victor Popov ${ }^{2}$ and Evheniia Tupytska ${ }^{2}$ \\ ${ }^{1}$ Kharkiv National Automobile and Highway University, Ukraine \\ ${ }^{2}$ YaroslavMudryi National Law University, Ukraine
}

\begin{abstract}
The article is devoted to the study of legal and economic relations that arise in the field of cargo transportation, in particular, their transshipment and legal grounds for its implementation. The article analyzes the legal nature of cargo handling in both the technological process and civil law services. It is determined that transshipment is a separate technological operation in the course of transportation and has its own basis for implementation, which serves as an agreement and therefore confirms and ensures the existence of a legal relationship between individual actors in economic turnover. The authors list the criteria for the economic efficiency of cargo handling, including delivery of cargo to the area where there are no certain types of transport; economic expediency of certain types of transport; and speeding up the delivery process. The European experience in using the cargo handling operation, the basis of the activity of logistic cents and the purpose of their functioning are analyzed. The statistical indicators of economic efficiency in the EU member countries are determined. The authors draw conclusions on the impact of European integration processes on the Ukrainian economy, in particular on the development of the logistics sector.
\end{abstract}

In the era of reaching the peak of commodity circulation both inside the countries and in international directions, the issue of cargo transportation remains one of the most urgent for modern society. The production and supply of certain goods in a territory is impossible without the proper functioning of the transport system, the coordinated interaction of the relevant elements, as well as the harmonization of economic and legal regulation of transportation relations. Despite the geographical location of Ukraine and the important place in the world's transport flows, as well as the potential for transportation of goods, our country is only the 80th among the 160 countries in the World Bank's LPI ranking (Logistics Performance Index [1] (Logistics Efficiency Index)) One of the consequences of the rapid development of European integration processes in Ukraine is its gradual access to the European Union transport space (hereinafter - the EU). This, in turn, leads to the need to create an effective legal framework that will meet modern social and economic requirements, as well as ensure proper trade between Ukraine and the EU countries and transit freight across the territory of Ukraine.

\footnotetext{
${ }^{1}$ Corresponding author: bocharova.n.a.xnadu@gmail.com
} 
Freight forwarding is an integral part of the direct shipment, irrespective of whether such transportation is carried out with the help of certain containers, tanks, etc. on the platforms of the relevant vehicles, or such cargo is loose or liquid and requires overloading or transfusion between separate capacities intended for transportation by separate types of transport. Cargo handling has a number of criteria for economic efficiency, both for carriers and for recipients of such services. In particular, they can be attributed to: 1) the delivery of cargo to the area where there is no type of transport which was the primary transportation; 2) even in the case of physical delivery of cargo to a certain area there is an economic expediency of transportation by a certain type of transport. This is the case, for example, of the air communication in which a cargo aircraft flies, for example, from New York to Kiev, while the goods must be delivered to Zhytomyr, in which case it is economically reasonable not to use air transport again, but simply to carry out the transshipment of goods to rail or road transport (if available); 3) Transshipment of cargoes can not only reduce the cost of transportation of cargo, but also accelerate the transport process. An important point, especially for perishable goods, is the possibility at any price to increase the speed of delivery of goods to the destination, changing the mode of transport at a certain stage of following the cargo can significantly accelerate the process of transportation, thereby reducing the likelihood of damage to goods.

With the cargo handling, a number of theoretical issues of the contractual sphere of economic relations are linked, as well as some aspects of the law enforcement practice. In particular, the issues of the subject structure of the relevant relations, distribution of the risks of loss or damage to the cargo, etc. are relevant. In this regard, it seems expedient to consider, within the scope of this study, the procedure for the transshipment of goods within the framework of relations with their carriage in direct and direct mixed traffic.

It is worth noting that the term "transshipment" is used in the laws and other special regulations on the transport of goods by different modes of transport. Part 3 of Art. 312 of the Commercial Code of Ukraine established the participation of the transshipment point in the transport of goods in direct mixed traffic. In this case, the relations of carriers during such transportation, as well as the conditions of operation of the transshipment points, are regulated by the agreement, the procedure of which is established by transport codes and statutes [2]. Thus, transshipment is a separate operation within the process of transportation, which should be considered as a legal relationship in which there are parties, an object, as well as content in the form of rights and obligations of the participants in the transportation process.

The answer to the question about the nature of the cargo handling operation and its place in the process of transportation is in the Service Provision Rules in seaports, where Clause 2.1. The definition of cargo operations is given. These include loading, unloading and overloading of cargo, loading and unloading of a vehicle. It is established that cargo operations are carried out on the basis of the relevant agreement [3]. In this regard, the question arises whether the transshipment process can include all the above operations? Clause 2.1 of the specified normative act stipulates that all types of operations are cargo and are carried out on the basis of the contract of transshipment, but along with this, in clause 3.3., it is assumed that the services related to the cargo operations that can be provided by the port operator, the terminal operator, include: load of goods; unloading of goods; clearing of holds of vessels, cars after unloading of cargoes; moving of cargo; technological accumulation of cargo, warehouse operations with cargo; fastening, special fastening of loads, etc. [3].

At present, the use of categories of transshipment, loading and unloading, in our opinion, is related to the designation of a specific part of the technological process carried out in the field of transportation. Any movement of goods by several modes of transport is associated with transshipment, but therefore the category of "load" is narrower and refers to 
the process of moving the goods to a particular type of transport, while the meaning of "transshipment" is wider and includes "shipment" to one vehicle and the actual load of another and is carried out for a specific purpose of delivering the goods.

As a cargo operation, transshipment, in this case, is an operation carried out at the stage of movement (transportation) of the cargo. Since cargo handling takes a clearly defined independent place in the transport process implemented on the basis of the separate civil law agreement, it can be considered as a service and as a technological operation provided (carried out) when transporting goods in direct combinations. At the same time, both legal and economic content of the relevant service are disclosed through the content of the operation. For example, the technological process of transshipment of petroleum products includes their acceptance at delivery points - at the railroad bridge or in the indicators of the system for measuring the quantity and quality of petroleum products at the delivery and receipt point (depending on the way of delivery of oil shipment to the seaport), oil transportation through oil pipelines to tank farms, formation of tanker batches, acceptance for storage, delivery to the pier, shipment to tankers and acceptance of oil stores from tankers. The above stages of the technological process, as O. Gavrilina points out, constitute a single comprehensive service for the handling of oil cargo through a specialized oil port with the purpose of their further removal outside the territory of the state. Taking into account the content of the said technological operation, the scientist states that the transshipment service involves the release of oil from railway tanks or the acceptance of the quantity of oil of the specified quality, delivery to the terminal tanks, accumulation and storage in the tanks of the terminal, delivery to the point of loading of oil cargoes and pouring them into a vessel (tanker) [4, p. 202, 206].

Thus, it can be concluded that the transshipment service provided in the course of the carriage of goods in direct mixed traffic is part of the legal relationship arising between the carriers on the basis of the carriage agreement and is absorbed by the legal relationship arising from the contract of carriage of cargo in direct mixed traffic. It should be noted that the content of the service in more detail can be disclosed through the means, methods and place of its provision. Transshipment services should be understood as material things, mechanisms and equipment, in particular, cranes, lifts, forklifts, overpasses, discharge systems, etc., through which the relevant service is provided.

Although the transshipment point is an integral part of the carriage of goods, these relations are not sufficiently regulated in domestic legislation because of obsolete approaches to property rights that arise in the field of transportation, since the Soviet legal system considered the infrastructure as an object of strategic importance. This also affected the fact that the probability of privatization of such objects was practically excluded. One can only recall what discussion arose about the possibility of privatization and its proper infrastructure after Ukraine gained independence. Although this type of private property is common in European countries. In practice it turned out that infrastructure objects began to be owned by separate legal entities using various mechanisms of privatization. As a result, due to the lack of a comprehensive program for the privatization of rail transport, they become new owners of newly created things. In addition, in uncomplicated cases, transshipment points are acquired by individuals, including by way of their privatization. Despite this, there is still no comprehensive approach to regulating ownership relations with transport infrastructure. Therefore, we can conclude that, against the background of fundamental changes in economic relations, since the 90's, the theoretical model of ownership has not undergone any changes [5, p. 32].

The domestic legislation provides for the possibility of staying transfer points in private ownership, as evidenced in particular by paragraph 9 of the Charter of Ukrainian Railways of [6]. The specified norm actually determines the possibility of staying of transfer points and access railroads in private ownership. In addition, in individual cases, the relevant 
objects are owned by individuals who are not registered in the Unified State Register of Legal Entities, Individual Entrepreneurs and Public Associations as Individual Entrepreneurs.

The current stage of development of the Ukrainian economy, especially in the context of European integration, gave a new impetus to the development of logistics in the middle of the country. One of the new directions of development of the domestic transport process is the creation of transport-logistic (logistics) centers. The practice of such centers is not new for Europe, since, for example, Interpol Bologna, which is currently one of the most important logistics platforms throughout Europe, has been active since 1971 [7, p. 203]. Starting in the 1990s, logistics centers are beginning to form in Europe as economic zones providing various transport and logistics services [8, p. 72].

The progressiveness and efficiency of the functioning of such centers is confirmed by the economic indicators of the European countries that have turned to the relevant practice. At present, the total volume of the European logistics services market is over EUR 600 billion. At the same time, logistics companies account for $30 \%$ of logistic functions in all branches of the economy. For example, in Holland the activity of transport and logistics centers brings $40 \%$ of the revenue of the transport complex, in France - 31\%, in Germany $25 \%$. The average in the countries of Central and Eastern Europe - 30\% [9, p. 32]. However, for the domestic legal system, this phenomenon is new.

In modern scientific literature there is a lack of a unified approach to the definition of a transport and logistics center. According to a study conducted by McMaster University at the request of the Ontario Ministry of Transport, there are more than 20 terms in the world that are intrinsically close and describe this phenomenon [10, p. 201]. Transport and logistics centers may have different names depending on local features of the place of operation. The literature determines the possibility of the existence of a transport and logistics center in the form of a transport node, which performs a wide range of tasks [11, $\mathrm{p}$. 115]. In Europe, such centers are called freight centers (Gueterverkehrszentren), intermodal Hub (Russia), multimodal platform, logistics areas, transport centers, etc. [12, p. 77]. In Japan, the logistics center is called a logistics hub [13, p. 215]. However, their most common name in world trade practices is "freight villages" [8, p. 72].

In general, transport and logistics centers are regarded as certain infrastructures equipped with all means to provide a range of services related to all transport operations, and cargo villages - as a specific region of the country, in which different market operators are provided with a full range of services relevant to transport and logistics distribution of goods for compatriots, as well as for international transit [14, p. 33]. Also in modern literature the transport and logistics center is considered as the center, which coordinates the use of different types of transport, performs loading and unloading and cargo handling, provides short-term and long-term cargo storage, cargo processing, execution of necessary customs procedures, inventory and freight forwarding, provides a set of service and commercial and business services, including banking, information, consulting and analytical services $[15$, p. 279]. M. V. Kondratyuk considers the transport and logistics center as a territorial association of independent companies engaged in cargo transportation and related services (for storage, maintenance and repair), which includes at least one terminal suitable for intermodal transport [16, p. 31-33]. The European Association of Cargo Villages and Logistics Centers (Euro platform) defines a logistics center as a center located within a defined territory, within which, on a commercial basis, different operators carry out activities related to transport, logistics and distribution of goods for national and international transportation. In this case, operators can be the owners or tenants of buildings and other infrastructure (warehouses, distribution centers, storage areas, offices, automobile services, etc.), which was built there [17]. 
The legal category of logistics centers has started to be used in domestic legislation recently and is associated with events in the East of Ukraine. The order of movement of goods to the district or from the area of the anti-terrorist operation, approved by Resolution of the Cabinet of Ministers of Ukraine of March 1, 2017 No. 99, contains the definition of the humanitarian-logistic center as a site on the controlled territory in the area of antiterrorist operation, where the retail and small-scale trade of food products is carried out, personal hygiene, clothing and footwear, household chemistry, as well as services, humanitarian and charitable assistance [18].

Although the transshipment point and the logistics center are not identical, they can perform similar functions from a functional point of view. The magnitude of the activities of transshipment points and logistics centers is different. Historically, the former are primarily engaged in the transshipment of goods, as well as, if necessary, their storage. At the same time, logistics centers provide a whole range of services, and when viewed as objects of transport infrastructure, they are considered as the unification of several such objects, for example, terminals with warehouse areas, platforms, offices, etc.

Thus, we can assert that the transshipment point and the logistics center are characterized by different approaches to the form of organization of transport processes. At the same time, in the current development of contractual relations, logistic centers exist as an economically and organizationally more progressive form of organization of cargo transportation, which provides the sender and carrier with a whole range of additional services. A logistics center can exist, in particular, in the form of a traditional transshipment point, but the transshipment point cannot be a logistics center due to the limited functionality defined by the provisions of regulatory acts [19, p. 129].

Summarizing the above, it should be noted that the gradual distribution of transport and logistics centers in our country creates a considerable basis for the development of the economy in the field of transport and logistics. Integration of Ukraine into the European space and the opening of new markets have created conditions for this development, especially as the commodity turnover constantly increases both within the country and in the foreign economy. The results of the introduction of new economic models can be noticed today, and consequently, the speed and quality of services provided in the transport sector are increasing. In turn, the provisions of the law regulating relations in the field of the operation of transshipment points require gradual changes. The legal basis in the form of legal acts regulating relations on the carriage of goods by various modes of transport, which was formed in the second half of the 20th century, is characterized by its efficiency and complexity. Evidence to this is that today the legal acts adopted during this period remain valid and they are effectively coping with the implementation of the regulatory function. However, the development of technological processes in the field of trade and the emergence of new transport infrastructure objects and new entrants in the relevant relations require the bringing of previously adopted regulations in line with the new requirements of the present.

\section{References}

1. International LPI global ranking URL: http://lpi.worldbank.org/international/global (access date: 03.05.2019).

2. Hospodars'kyy kodeks Ukrayiny: Zakon Ukrayiny vid 16.01.2003 № 436-IV. Vidom. Verkhov. Rady Ukrayiny, 18, 144 (2003)

3. Pravyla nadannya posluh u mors'kykh portakh Ukrayiny: zatv. nakazom M-va infrastrukt. Ukrayiny vid 05.06.2013 r. № 348. Ofits. visn. Ukrayiny, 65, 2352 (2013) 
4. E.A. Gavrilina, Sistema dogovornykh svyazey na rynke nefti i nefteproduktov. M., 244 (2014)

5. M. Domashenko. Pravo Ukrayiny, 12, 32-39, (2010)

6. Pro zatverdzhennya Statutu zaliznyts' Ukrayiny: postanova Kabinetu Ministriv Ukrayiny vid 06.04.1998 r. № 457. Ofits. visn. Ukrayiny, 14, 548 (1998)

7. Postanova Vyshchoho hospodars'koho sudu Ukrayiny vid 8 lyst. 2016 r., sudova sprava № 914/595/16. URL:http://reyestr.court.gov.ua/Review/62724626.

8. S. M. Bonyar, Y.R.Korniyko. Investytsiyi: praktyka ta dosvid, 7, 71-72 ( 2012)

9. M. V. Kondratyuk, Visn. ekonomiky transportu i promyslovosti, 47, 31-33 (2014)

10. Postanova Vyshchoho hospodars'koho sudu Ukrayiny vid 8 lyst. 2016 r., sudova sprava № 914/595/16 URL: http://reyestr.court.gov.ua/Review/62724626

11. O. E. Sokolova. Naukoyemni tekhnolohiyi, 1 (21), 114-118 (2014)

12. O. V. Nelipovych, S. A. Popel', K. D. Motyuk. Mytna bezpeka, 2, 76-82 (2013)

13 K. S. Romanenko. Materials of III sciences conference (Odessa, 22-23 Nov. 2013). Phoenix, 214-217 (2013)

14. S. M. Bonyar, YA. R. Korniyko, Ekonomika ta derzhava, 3, 32-35, (2012)

15. N. M. Dashchenko. Project management, system analysis and logistics. Technical series, 8, 278-282 (2011)

16. N. A. Butakova, Pravovoye regulirovaniye mul'timodal'noy perevozki gruzov: komparativnyy podkhod, M., 494 (2016)

17. Logistics Center Definition. URL: http://europlatforms.eu/Logistic \%20CenterDefinition.html (access date: 11.05.2019).

18. Pro zatverdzhennya Poryadku peremishchennya tovariv do rayonu abo z rayonu provedennya antyterorystychnoyi operatsiyi: postanova Kabinetu Ministriv Ukrayiny vid 01.03. 2017 r. № 99. Ofits. visn. Ukrayiny, 21, 592 (2017)

19. Vozdushnyy kodeks Soyuza SSR : utverzhden Ukazom Prezidiuma Verkhovnogo Soveta SSSR ot 11.05 .1983 g. № 9575-KH. URL: http://www.libussr.ru/doc_ussr/usr_11552.htm (дата обращения: 17.05.2019). 